\title{
Proposed strategies for designing sustainable high-rise apartment buildings in Ho Chi Minh City responding to critical urban issues
}

\author{
Nguyen Hoang Long Truong ${ }^{1, *}$, Ngoc Huan Giang ${ }^{1}$ and Trong Binh Duong ${ }^{1}$ \\ ${ }^{1}$ University of Architecture Ho Chi Minh City, 196 Pasteur str., Ward 6, District 3, Ho Chi Minh City, \\ Vietnam
}

\begin{abstract}
This paper aims at finding practical strategies for designing sustainable high-rise apartment buildings in Ho Chi Minh City responding to varied municipal issues. Two steps are made. Step-1 identifies the critical issues of Ho Chi Minh City which are associated with high-rise apartment building projects. Step-2 finds potential and applicable strategies which are solutions for the critical issues in Step-1 with reference of seven selected assessment methods. The study finds the set of 58 strategies applicable to designing sustainable high-rise apartment buildings in Ho Chi Minh City.
\end{abstract}

\section{Introduction}

The emerging term 'sustainable development' proclaimed initially in the 1987 World Commission on Environment and Development has caught widespread concerns and become the global tendency responding to the critical environmental matters of greenhouse gas (GHG), global warming, and climate change [1]. The concept of sustainable development is acknowledged to be an intersection of the environmental, social and economic dimensions which are interrelated and interdependent to form the comprehensive approach of an issue [2]. Regarding built environment, sustainable design is a three-dimensional thinking of problem-solving. The strategies for sustainable design in planning, design, and construction should be studied in a local situation and diverse contexts in order to achieve large effects of sustainability on the global scale.

Vietnam government has profoundly proclaimed that sustainable development is a crucial future of the country. Vietnam early affirmed the sustainable development at the 1992 Rio Earth Summit and again concretized that affirmation at the 2002 Johannesburg Earth Summit as launching the National Agenda 21 which was domestically introduced in the Decision No. 153/2004/QD-TTg, namely, 'The Strategic Orientation for Sustainable Development in Vietnam.'

Ho Chi Minh City (HCMC), the most concentration of population and development in Vietnam, recently has a remarkable increase in developing high-rise apartment buildings (HAB) for meeting the great accommodating demands of citizens. High-rise dwellings are determined as the only solution for solving the housing demands in the coming decades in

\footnotetext{
${ }^{*}$ Corresponding author: long.truongnguyenhoang@uah.edu.vn
} 
the urban area of HCMC. Recent official proclamation intensively insists that developing apartment housing must be the principal priority for all new residential projects developed in the major cities of Hanoi and HCMC. It particularly targets that the ratios of apartment buildings in new residential projects in HCMC must reach $80 \%$ in 2015 and $90 \%$ in 2020 respectively [3, 4]. HCMC today has been in the progress of upgrading and transforming urban housing from low-rise townhouses to HAB. It is expected that high-rise residences development is the potential solution for reserving land for infrastructures, public facilities, and green spaces, as well as facilitate municipal management and public transportation development [5]. However, most of built and ongoing HAB projects were profoundly carried out in the profit-oriented driven rather than the ecological and social establishment [6]. In addition, although sustainable high-rise residence has become a majority in the prospective period, the relative supports for HAB design are insufficient. The demand for practical design strategies thus is greatly appreciated.

Although there are multiple of green building assessment tool dedicated for Vietnam such as LOTUS rating system of Vietnam Green Building Council (VGBC), EDGE Resource Efficiency Certifications in Vietnam of International Finance Corporation (IFC) supporting $\mathrm{HAB}$, the contents of criteria specify the general aspects of environmental issues and comprehensive Vietnam context rather than HCMC urban critical issues typically. Aside from that, the available rating systems are constructed with a huge set of criteria dedicated for rating and pointing the integral building life cycle but for guiding design procedures. They are therefore complicated for common planners, investors, or designers. This problem is the gap for this paper to fill in. This paper focuses on the practical strategies for designing sustainable $\mathrm{HAB}$ in $\mathrm{HCMC}$, which are driven by the presently critical issues of the city.

\section{Literature review}

Many scholars have conducted studies on the designing sustainable HAB in HCMC and brought about multiple aspects of literature. Environmental issues of HAB is greatly studied in the thesis of Giang [7] and Le [8]. Giang [7]'s master thesis works on design methods for $\mathrm{HAB}$ in HCMC towards micro-climatic comforts and climate-driven energy-efficiency with analyzing traditional/vernacular houses and drawing lessons of climatically responsive design methods. However, this thesis merely investigates the climatically responsive aspects of $\mathrm{HAB}$ rather than a comprehensive approach to $\mathrm{HAB}$ as a whole. In another aspect, Le [8] suggests models of HAB in Vietnam based on lessons of passive and unique characteristics learned from Vietnamese vernacular houses. In her doctoral dissertation, two stages were carried out, analyzing case studies of vernacular houses and townhouses for collecting passive design strategies and suggesting typical models for HAB applicable to Vietnamese condition. Although this dissertation conducts research to detailed models of HAB but the solutions presented in the proposed models are hard to be applied in the actual construction industry.

Recently, there are noticeable two studies on sustainable HAB in HCMC, including Truong [9] and Giang [10] doctoral dissertation. The former provides a guidelines framework for $\mathrm{HAB}$ in HCMC and the latter provides criteria system of sustainable architecture for designing $\mathrm{HAB}$ in Ho Chi Minh City. The both studies consider the sustainability terms in integral three dimensions. However, Giang [10] attempts to provide comprehensive rating system with environmental, social and economic dimensions which result in the criteria system huge and complicated to be applied. Meanwhile, Truong [9] covers the urban and general sustainability issues to establish a framework of criteria dedicated for composing guidelines. 
In general, despite multiple studies on sustainable HAB in HCMC, practical strategies easily applicable to designing sustainable HAB in HCMC are still opaque. This shortage of knowledge is an opportunity that paper aims to tackle.

\section{Materials and methods}

The strategies of sustainability applicable to HAB in HCMC should stem from the critical issues of HCMC urban and match with the local construction industry, designing and constructing techniques and living context. Local context, thus, should be attached to the process of study and become a key axis throughout the study. This study is designed to conduct in two steps, including Step-1 and Step-2. Step-1 identifies the critical issues of HCMC urban which are associated with HAB projects. Step-2 finds potential and applicable strategies built as solutions for the critical issues in Step-1 with reference to criteria of seven selected green building assessment methods. The procedure of the study is summarized in below diagram (Fig. 1).

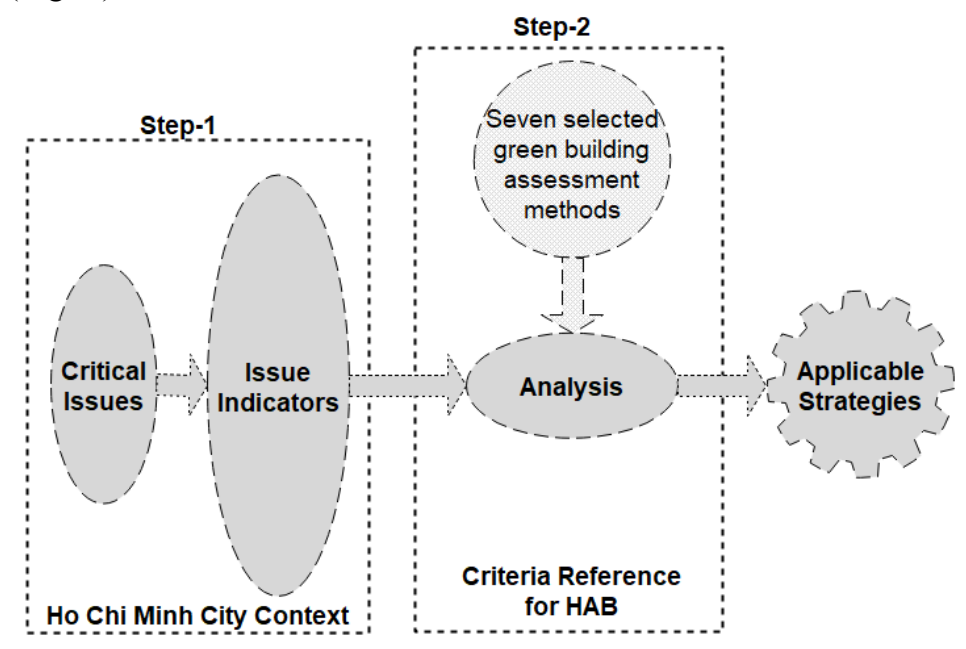

Fig. 1. Research diagram

Step-1 works on secondary data which is mostly used for documentary analysis. The data derives from various relevant sources, including books, narratives, reports, journals, magazines, archival data, and websites with intent to figure out a scenario of critical issues and its indicators. The result of Step-1 is the issue indicators of all critical urban issues.

Step-2 works on finding solutions for solving the issue indicators found in Step-1. Reference sources for strategies are seven selected green building assessment methods prevalent in the international, regional and domestic scale, all of which support designing HAB. Analyzing is the basic method used in this process. The proposed strategies are built on an integral reference and actual HAB built environment in HCMC. The documents of seven selected assessment methods are popular and available for downloading from organizational websites (Table 1).

Table 1. Seven selected green building assessment methods 


\begin{tabular}{|c|c|c|c|c|c|c|c|}
\hline No. & Sign & Assessment Method Title & Version & 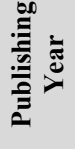 & Country & $\begin{array}{l}\bar{\Xi} \\
\frac{0}{0}\end{array}$ & 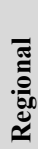 \\
\hline 1 & (1) & $\begin{array}{l}\text { Leadership in Energy and } \\
\text { Environmental Design }\end{array}$ & LEED-NC V.3 & 2009 & USA & $\checkmark$ & \\
\hline 2 & (2) & Code for Sustainable Homes & - & 2010 & UK & $\checkmark$ & \\
\hline 3 & (3) & $\begin{array}{l}\text { The Comprehensive Assessment } \\
\text { System for Building Environmental } \\
\text { Efficiency (CASBEE) }\end{array}$ & CASBEE-NC & 2014 & Japan & $\checkmark$ & \\
\hline 4 & 4 & BCA Green Mark Scheme & 4.1 & 2012 & Singapore & & $\checkmark$ \\
\hline 5 & (5) & Green Building Index (GBI) & GBI-RNC 3.1 & 2014 & Malaysia & & $\checkmark$ \\
\hline 6 & $\boldsymbol{6}$ & $\begin{array}{l}\text { Building for Ecologically } \\
\text { Responsive Design Excellence } \\
\text { (BERDE) }\end{array}$ & $\begin{array}{l}\text { BERDE-NC- } \\
\text { VRD } 1.1 .0\end{array}$ & 2013 & The Philippines & & $\checkmark$ \\
\hline 7 & $\boldsymbol{\theta}$ & LOTUS & LOTUS-R EP & 2013 & Vietnam & & $\checkmark$ \\
\hline
\end{tabular}

\section{Results}

\subsection{Step-1: Identifying critical issues of HCMC}

As common megacities in emerging countries, $\mathrm{HCMC}$ urban area today are inevitably struggling with various chronic problems in the urban living environment which are threatening the living quality and environment of HCMC.

\subsubsection{Climate and Foreseen Climate Change}

\section{a. Urban Climate}

Located in the tropical equatorial monsoon, the climate of HCMC is typically hot and humid with two distinctive seasons: the rainy season, from May to November, and the dry season, from December to April. Generally, HCMC has high air temperature and humidity; absorbs a great amount of solar radiation; and receives monsoons all year round $[11,12]$.

\section{Air Temperature}

Since HCMC is located in the tropical equatorial climate zone, the air temperature is quite high. The city is reported to receive $140 \mathrm{Kcal} / \mathrm{cm}^{2}$ per year with insolation time of 5-9 hours per day and 160-270 hours per month. The annually average temperature is as high as $27^{\circ} \mathrm{C}$ and 330 days per year have the average temperature of $25-28^{\circ} \mathrm{C}$. April is the hottest month with the highest mean temperature $\left(28.8^{\circ} \mathrm{C}\right)$ while the average temperature is lowest $\left(25.7^{\circ} \mathrm{C}\right)$ between December and January. The absolute highest and lowest temperatures are $40^{\circ} \mathrm{C}$ and $13.8^{\circ} \mathrm{C}[11,12]$.

\section{Humidity}

The humidity is slightly high in HCMC. The mean relative humidity is $79,5 \%$ in annual, particularly $80 \%$ in the rainy season and $74.5 \%$ in the dry season. The absolute highest humidity is $100 \%$ while the lowest is $20 \%[11,12]$.

\section{Rainfall}

The rain intensity in HCMC region is significantly high. The annually average rainfall reaches $1,949 \mathrm{~mm}$ and approximately $90 \%$ of which happens in the rainy season from May to November. The average number of rainy days in annual is 159 days. June and September are the two months recorded the highest rainfall while January, February, and March having no significant rainfall events $[11,12]$. 


\section{Prevailing Wind Directions}

Two principal prevailing monsoons are corresponding to the two seasons, including the west-southwest monsoon flowing in the rainy season, from May to November, and northnortheast monsoon flowing in the dry season, from December to April. The west-southwest monsoon comes from the Indian Ocean with the average speed of $3.6 \mathrm{~m} / \mathrm{s}$ and reaching the highest speed of $4.5 \mathrm{~m} / \mathrm{s}$ in August. The north-northeast monsoon comes from the East Sea with the average speed of $2.4 \mathrm{~m} / \mathrm{s}$. Aside from the two main monsoons, the south-southeast monsoon occurs between March to May with the average speed of $3.7 \mathrm{~m} / \mathrm{s}$. Specifically, HCMC is located out of typhoon zone while the typhoon often strikes from the North to South Central Coast of Vietnam [11, 12].

\section{b. Foreseen Climate Change}

The impacts of climate change have evidently acknowledged in Vietnam. Vietnam was enumerated into the most vulnerable countries suffering the consequences of climate change seriously [13]. Specifically, HCMC locates in the high-effect zone of this influence. Recent researchers show evidence that there are relations of climate change and unfavorable changes in weather factors in HCMC, such as increasing air temperature, rainfalls, and sea-level rise [14]. The air temperature in HCMC tends to increase significantly in the coming decades. The average temperature is projected to increase $1^{\circ} \mathrm{C}$ by 2020 and $2.6^{\circ} \mathrm{C}$ by 2100 [15]. Besides, the rainfall tends to decline during the dry season and increase during the rainy season [15]. Statistical documents of rainfall show an increasing trend of the intensity of annual highest intensity rainfalls with an average rate of about $0.8 \mathrm{~mm}$ per year and frequency of high intensity (greater than $100 \mathrm{~mm}$ ) rainfalls is clearly enhanced (

Fig. 2 and Table 2). In addition, sea levels are predicted to rise $30 \mathrm{~cm}$ by 2050 and 65 $100 \mathrm{~cm}$ by 2100 compared with average sea level during the period 1980-1999 [15]. Consequently, the increasing frequency of heavy rains higher than $100 \mathrm{~mm}$ combined with more serious tidal flooding due to sea-level rise contributes critical urban inundation in HCMC urban area.

$\mathrm{mm}$

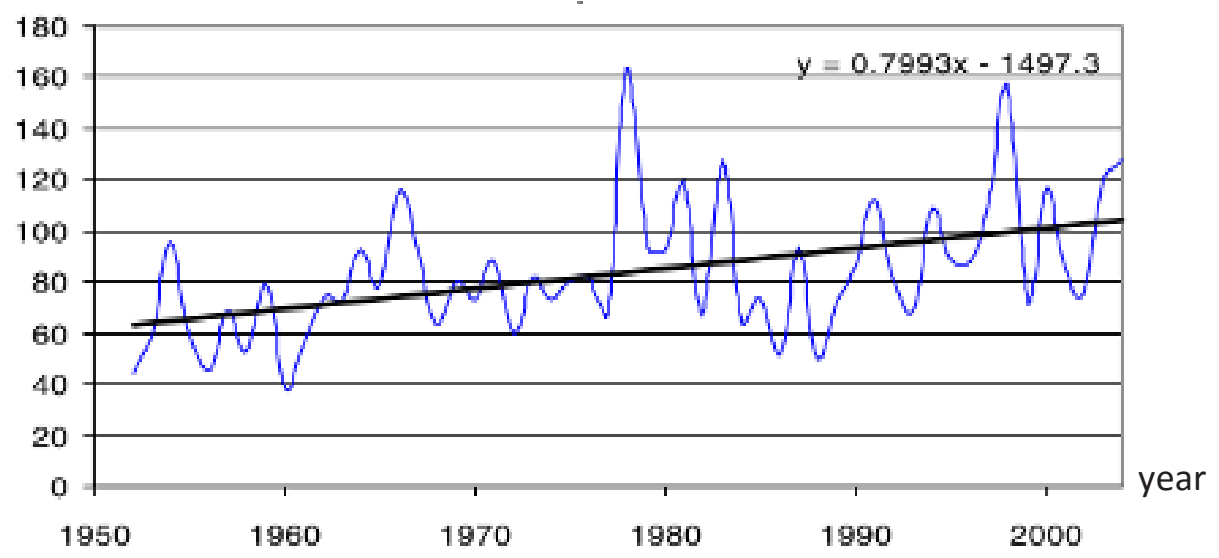

Fig. 2 Trend of highest intensity rain in HCMC [16]

Table 2 The frequency of high-intensity rainfall (greater than $100 \mathrm{~mm}$ ) lasting 180 minutes [16]

\begin{tabular}{|l|l|l|l|l|l|}
\hline Period & $1952-1961$ & $1962-1971$ & $1972-1981$ & $1982-1991$ & $1992-2002$ \\
\hline
\end{tabular}




\begin{tabular}{|l|l|l|l|l|l|}
\hline $\begin{array}{l}\text { Occurred } \\
\text { Times }\end{array}$ & 0 & 1 & 2 & 2 & 4 \\
\hline
\end{tabular}

\subsubsection{Environmental Risks}

\section{a. Energy Consumption and Greenhouse Gas Emission}

Located in the tropical belt, Vietnam possesses rich sources of renewable energy including solar energy, wind energy, and biomass. Despite having high potentials of renewable energy, majority energy consumed in HCMC is fossil fuel based sources and the exploitation of renewable energy is modest. The records show that HCMC consumes onethird of nationwide commercial energy, daily consumes 40 million $\mathrm{kWh}$ and annually consume 14.6 billion $\mathrm{kWh}$ [5]. As a result, the greenhouse gas emission in HCMC is extremely increasing since the volume of greenhouse gas emitted is proportional to the amount of fossil fuel energy consumed. HCMC is responsible for one fourth of the nationwide greenhouse emission originated from oil and coal consumption [5].

Due to climatic characteristics of HCMC, a large portion of electricity is consumed in residential buildings for maintaining a thermally comfortable indoor environment. Dehumidification and refrigerated cooling are primary strategies to alleviate overheat and humid air. With the development of mechanical cooling technologies, designers, builders, and owners misused the HVAC equipment without considering the energy efficient systems or indoor thermal comfort management. The rising household incomes accelerates the demands of using air conditioning for cooling interiors, in both office and residential buildings [17].

Besides, the greenhouse emission is also directly from material processing and transportation. A large portion of private motorcycle vehicles is the principal contributor to air pollution, noise pollution, and $\mathrm{CO} 2$ emission.

\section{b. Emissions into Land and Water}

The construction activities are evidently taking a large part in land and water sources degradation in the HCMC. The expansion of the construction site to the vegetated areas, river and canal banks during urbanization process has reduced significantly the greenery area and narrowed the water surface. Due to the high demands of housing, a considerable greenery areas are cleared for construction purposes without recovering after finishing construction. HCMC urban area possesses multiple rivers and canals for regulating the water flows. However, the recent urban expansion shows that many large apartment projects lie at banks of the rivers and canals and sometimes even encroach on the rivers and canals. These actions have accelerated the flow alteration, river bank erosion, and urban inundation. Besides, the construction sites are often backfilled, leveled and remained empty long before the actual constructing activities to be carried out, which brings about erosion, land slips under heavy rains, and causing critical pollution in land and water sources.

Moreover, HCMC construction activities contribute to solid waste with an essential proportion disposed into landfills. Reducing wastes is seldom paid attention in planning and design process. Most of the contractors do not consider seriously for classifying waste at construction sites and disposing of their construction waste in landfills. Only a small number of large contractors ready to pay more for waste management and disposition, the medium and small builders, however, often ignore treating waste properly. Moreover, most of the landfill sites are open to nature and lack of essential safety environmental protection methods to stop the solid waste, especially hazardous elements from penetrating into the soil, groundwater, river and the sea. These facts result from the unawareness of environmental 
protection, lack of public responsibility toward general safety, imbalance between profits and environmental preservation.

\section{c. Urban Inundation}

Urban inundation has been a critical problem in HCMC. Many factors contribute to the flooding in HCMC, from natural elements such as low elevation, heavy rainfall, flood tide, and sea level rises to improper human activities in urban planning and construction activities. Vietnam belongs to the top ten countries that their land and population is situated in lowlying coastal areas, $10 \mathrm{~m}$ above mean sea level [18]. HCMC is situated mostly on low-lying and marshy land in the north-eastern plain of Mekong Delta, the most vulnerable to flooding due to its low-level plain, population concentration, and economic activities. HCMC metropolitan area has a quite low level when $55 \%$ of the urban area is situated on one meter above mean sea level and only $28 \%$ is placed on two-meter level.

Sea level rise due to climate change is also a threatened potential since HCMC is $50 \mathrm{~km}$ from the sea. The sea level is reported to rise at the rate of $2-4 \mathrm{~cm}$ per decade and could rise $30 \mathrm{~cm}$ by $2050,75 \mathrm{~cm}$ by 2100 when $10 \%$ of the area of $204 \mathrm{~km}^{2}$ will be inundated.

The mixture of factors including flood tide, sea level rise, and rainfall accelerates urban flooding in HCMC. The records show that if the occurrence of heavy rainfall over $100 \mathrm{~mm}$, coinciding with the flood tide, the long spell of extensive flood might occur [19]. The flooding has occurred in most districts and seriously affected the health, living activities, and production of citizens. The prolonged heavy rains often cause various roads of districts, e.g. District 6, 8, 11, Tan Phu, and Binh Tan, immersed in water, even in the new road and districts. This fact drives the city to face various side problems such as traffic congestion, environmental pollution, and public diseases.

Aside from the natural factors, improper human activities are also the reasons for the urban flooding, for example, the weak management in water conservation projects. To cope with the urban inundation, the city has carried out multiple steps for controlling flooding through many projects for renewing the capacity of the basin and drainage of canals such as Nhieu Loc - Thi Nghe, Tau Hu - Ben Nghe, Tan Hoa - Lo Gom. However, the implemented solutions partially solve the flooding in central areas, but new areas appear to be a brand new inundated place, especially in suburban areas. Due to the weak management of drainage infrastructure deployed projects, most of 'anti-flood' projects, however, have not been met the requirements and progress schedules.

\subsubsection{Socio-Economic Issues}

\section{a. Shortage of Greenery and Open Space}

Standards for the public greenery area and open space has been early prescribed in Vietnam planning and construction standards. The detailed ratio of greenery land for public use is defined in Decision 01/2006/QD-BXD with particular requirements as Table 3. Accordingly, HCMC, an extraordinary urban, must adopt the public greenery land as high as 12-15 $\mathrm{m}^{2}$ per person. However, the city's greenery and open space for the public purposes, in reality, has been modest and unevenly distributed. Even though actual greenery area average per capita citywide reaches $13.74 \mathrm{~m}^{2}$, the inner city attains only $1.95 \mathrm{~m}^{2}$ per capita while suburban achieves an enormous number, $473.6 \mathrm{~m}^{2}$ per capita [5]. The picture seems to get worse when the ratio of the greenery urban area tends to decrease in the context of increasing demands for city's infrastructure expansion and population concentration.

Table 3 Standard of area greenery land for public use [20]

\begin{tabular}{|l|l|l|l|l|}
\hline & $\begin{array}{l}\text { Standard of } \\
\text { greenery land for } \\
\text { public use } \\
\left(\mathrm{m}^{2} / \text { person }\right)\end{array}$ & $\begin{array}{l}\text { Standard of green } \\
\text { park land } \\
\left(\mathrm{m}^{2} / \text { person }\right)\end{array}$ & $\begin{array}{l}\text { Standard of } \\
\text { gardens plants land } \\
\left(\mathrm{m}^{2} / \text { person }\right)\end{array}$ & $\begin{array}{l}\text { Standard street } \\
\text { trees land } \\
\left(\mathrm{m}^{2} / \text { person }\right)\end{array}$ \\
\hline
\end{tabular}




\begin{tabular}{|l|l|l|l|l|}
\hline Extraordinary & $12-15$ & $7-9$ & $3-3.6$ & $1.7-2$ \\
\hline I \& II & $10-12$ & $6-7.5$ & $2.5-2.8$ & $1.9-2.2$ \\
\hline III \& IV & $9-11$ & $5-7$ & $2-2.2$ & $2-2.3$ \\
\hline V & $8-10$ & $4-6$ & $1.6-1.8$ & $2-2.5$ \\
\hline
\end{tabular}

Responding to this situation, the city government has implemented many actions. In 2000, a project of HCMC's green park planning until 2010 was approved to set a short-term target for the city [21]. The greenery urban park must reach an average of 6-7 $\mathrm{m}^{2}$ per capita by 2010, not including street trees, isolated trees in the industrial park, and private housing trees, of which, the existing urban is 3-4 $\mathrm{m}^{2}$ per capita and new urban is $8-10 \mathrm{~m}^{2}$ per capita. However, the above project was finally failed. The statistical data carried out at the end of 2011 showed an unexpected urban green park area achieved merely less than one $\mathrm{m}^{2}$ per capita [22]. HCMC administrators also made an effort to bring about greenery spaces by renovating existing urban systems through projects in 2009 with strategies learned from cases of Singapore. Accordingly, 28,000 $\mathrm{m}^{2}$ of sidewalk in the old districts (District 1,3,5, and 10) was recovered with greenery area of grasses and plants. Besides, there were approximately $13,000 \mathrm{~m}^{2}$ of land was covered with the green landscape in the overhead bridge sites such as An Suong, Tan Thoi Hiep, Nga Tu Ga and Tan Thuan overhead bridges [22].

Although taking many efforts to fill the gap of greenery area, HCMC government impossibly manages the ratio as the standard required. The principal reason is that many residential projects did not comply with greenery area as planned. Much of the land reserved for developing greenery space is used for another purpose due to economic issues. Meanwhile, the official managers did not fulfill their monitoring functions.

\section{b. Transportation Issues}

The city planning is still imperfect, and the public transportation facilities are limited. The urban rail systems, e.g. subway, are under construction while the bus systems are not favorable to public use. As a result, the majority of people prefer using the private vehicles, e.g. motorcycle and car. Accompanying with the predominant townhouses in HCMC, the motorcycle has been the most popular vehicles serving transportation demands of people. Highly relying on private motorcycles leads to a number of side effects in urban area such as greenhouse gas emission, air and noise pollution, traffic congestion, accidents, and disorder city residence. The city environment is significantly polluted with dust, noise and polluted air. Traffic congestion has been a critical issue in HCMC when the growth of traffic volumes is increasing over the existing road networks' capacity.

For reducing congestion and $\mathrm{CO}_{2}$ emission, in recent decades, the government has released policies to promote using bus systems in the city center with the efforts reducing the number of private motorcycles, however, the effects of those policies remain modest. In addition, the long-term mass transit systems, e.g. subways and sky trains, have been planned and constructed with the high expectation to be a good solution for solving the traffic issues.

\section{c. Living Habits \& Culture}

\section{Lack of public interests on sustainability}

The majority of public in HCMC have been indifferent to the issues of sustainability due to the diverse reasons. This results from both managers and citizens' sides. From managers' side, the term sustainable development and its related themes have not been evidenced yet in the system of national laws, policies, and standards. The municipal planning has not been consistently connected with long-term plans on socio-economic development towards environment-friendly [23]. The city administrators are spending time for abundant social problems rather than issues of sustainability. On the public side, the environmental sustainability is likely not an urgent or mandatory issue rather than their 
basic living demands. Also, the environmentally friendly design or construction is often thought to be more expensive than the common method. People often believe that green building is accompanied with the huge additional fees. As a result, organizations and businesses have no interest in issues of green building due to lack of financial motives.

Particularly, the limited knowledge and technology have narrowed the boundary of strategies for energy efficiency, reuse and recycle materials. The shortage of typically sustainable design also diminishes the encouragement for sustainable design. Weak financial foundation, short-term business and backward constructing fashions have hindered the research and implement the sustainable design and construction. The materials and equipment associated with sustainable construction are often imported that increases cost.

\section{Living habits}

The traditional Vietnamese village contributes intimate community connectivity among villagers through the close interaction and cooperation among residents in the common daily activities. Since traditional village acts as an independent administrative and economic unit, the order and relationship among residents are defined by the village customs that are sometimes more powerful than the remote king's rule as a Vietnamese proverb said: 'The will of king yields to the people's customs.' In this sense, community connectivity has become distinctively cultural identities of the Vietnamese community [24]. However, the community sense in municipal modern living has greatly changed which results in various drawbacks on social life.

Besides, the common living habits of Vietnamese have specific manners of space arrangement and living which are blurred in the urban living, especially in HAB. All the critical issues of HCMC are summarized in Table 4 with the detailed issue indicators.

Table 4 Summary of critical issues of HCMC and issue indicators

\begin{tabular}{|c|c|c|}
\hline Critical issue & Sub-issue & Issue indicator \\
\hline \multirow{2}{*}{$\begin{array}{l}\text { A. Climatic } \\
\text { issues }\end{array}$} & \multirow{2}{*}{$\begin{array}{l}\text { A1 Harsh } \\
\text { climate \& } \\
\text { climate } \\
\text { change } \\
\text { effects } \\
\end{array}$} & A1.1 Overheating \\
\hline & & A1.2 High rain intensity \\
\hline \multirow{7}{*}{$\begin{array}{l}\text { B. } \\
\text { Environmental } \\
\text { risks }\end{array}$} & \multirow{3}{*}{$\begin{array}{l}\text { B1 GHG } \\
\text { emission }\end{array}$} & B1.1 Low rate of renewable energy use \\
\hline & & B1.2 High demand of air-conditioning system \\
\hline & & B1.3 Materials processing \\
\hline & \multirow{2}{*}{$\begin{array}{l}\text { B2 Emission } \\
\text { into land and } \\
\text { water }\end{array}$} & B2.1 Land erosion and river/canal pollution \\
\hline & & B2.2 High amount of solid waste \\
\hline & \multirow{2}{*}{$\begin{array}{l}\text { B3 Urban } \\
\text { inundation }\end{array}$} & B3.1 Low level land \\
\hline & & B3.2 Weak water conservation infrastructure \\
\hline \multirow{8}{*}{$\begin{array}{l}\text { C. Socio- } \\
\text { Economic } \\
\text { issues }\end{array}$} & \multirow{2}{*}{$\begin{array}{l}\text { C1 Shortage of } \\
\text { greenery } \\
\text { and open } \\
\text { space }\end{array}$} & C1.1 Lack of public open space \\
\hline & & C1.2 Lack of greenery land \\
\hline & \multirow{4}{*}{$\begin{array}{l}\mathrm{C} 2 \\
\text { Transportation }\end{array}$} & C2.1 Overloaded private vehicles \\
\hline & & C2.2 Unattractive public/bus transportation \\
\hline & & C2.3 Noise, polluted air, accidents \\
\hline & & C2.4 Traffic congestion \\
\hline & \multirow{2}{*}{$\begin{array}{l}\text { C3 Living habits } \\
\text { \& culture }\end{array}$} & C3.1 Lack of community connectivity \\
\hline & & C3.2 Low-rise/Townhouse living habits \\
\hline
\end{tabular}




\subsection{Step-2: Finding applicable strategies}

Step-2 finds applicable strategies built as solutions for the critical issues in Step-1 with reference to criteria of seven selected green building assessment methods. A strategy could be the solution for multiple issue indicators, of which, a primary issue indicator is the main issue-driven strategy. Table 5 represents all outcomes of the analysis in Step-2. The far right column represents the reference sources that are referred in the certain strategy.

Table 5 Proposed strategies built from solutions of issue indicators

\begin{tabular}{|c|c|c|c|c|}
\hline $\begin{array}{l}\text { Primary issue } \\
\text { indicator }\end{array}$ & No. & Proposed strategy as solution & $\begin{array}{l}\text { Secondary } \\
\text { issue } \\
\text { indicator }\end{array}$ & $\begin{array}{l}\text { Reference } \\
\text { sources }\end{array}$ \\
\hline \multirow[t]{10}{*}{$\begin{array}{l}\text { A1.1 } \\
\text { Overheating }\end{array}$} & 01 & $\begin{array}{l}\text { Optimizing the building orientation (facing } \\
\text { south) }\end{array}$ & B1.1 & $\boldsymbol{8}$ \\
\hline & 02 & Incorporate the buffer space (balcony or loggia) & B1.1 & - \\
\hline & 03 & $\begin{array}{l}\text { Provide buffer spaces (staircases, lifts, store, } \\
\text { toilets, etc.) on majority of the west wall }\end{array}$ & B1.1 & - \\
\hline & 04 & $\begin{array}{l}\text { Incorporating exterior shading devices; vertical } \\
\text { greenery system }\end{array}$ & $\mathrm{B} 1.1$ & $\begin{array}{l}\text { (1), (3), } \mathbf{4} \\
\mathbf{5 ,} \mathbf{6}, \mathbf{7}\end{array}$ \\
\hline & 05 & $\begin{array}{l}\text { Provision of thermal insulation on building } \\
\text { envelope; vegetated roof }\end{array}$ & B1.1 & $\begin{array}{l}\text { (3), } \mathbf{4}, \mathbf{6} \\
\mathbf{6}, \mathbf{7}\end{array}$ \\
\hline & 06 & $\begin{array}{l}\text { Light color textures and rough textures for } \\
\text { building external facades, roofing and hardscapes }\end{array}$ & $\mathrm{B} 1.1$ & $\begin{array}{l}\text { (1), (3), } \mathbf{5}, \\
\mathbf{6}, \boldsymbol{\nabla}\end{array}$ \\
\hline & 07 & $\begin{array}{l}\text { Provide shade from a tree canopy, solar panels } \\
\text { structures or solar reflective architectural } \\
\text { structures }\end{array}$ & B1.1 & $\begin{array}{l}\text { (1), } \mathbf{5}, \mathbf{6} \\
\mathbf{7}\end{array}$ \\
\hline & 08 & $\begin{array}{l}\text { Interior sunlight control elements (e.g., curtain, } \\
\text { drapes, blinds, adjustable louvers) }\end{array}$ & B1.1 & - \\
\hline & 09 & $\begin{array}{l}\text { Selecting appropriate glazed size for daylighting } \\
\text { and avoiding excessive illumination levels inside } \\
\text { the building }\end{array}$ & $\mathrm{B} 1.1$ & (5 \\
\hline & 10 & $\begin{array}{l}\text { Use appropriate double-glazed units with Low-e } \\
\text { glass, or glass coatings }\end{array}$ & B1.1 & 5 \\
\hline \multirow[t]{2}{*}{$\begin{array}{l}\text { A1.2 High rain } \\
\text { intensity }\end{array}$} & 11 & $\begin{array}{l}\text { Design drainage systems that adequately dispose } \\
\text { of rainwater and prevent flooding from excessive } \\
\text { runoff }\end{array}$ & B3.2 & - \\
\hline & 12 & $\begin{array}{l}\text { Use permeable/pervious paving materials or open } \\
\text { grid pavement system for hardscapes }\end{array}$ & B3.2 & $\begin{array}{l}(1),(2),(3), \\
\mathbf{5}, \mathbf{7}\end{array}$ \\
\hline \multirow[t]{7}{*}{$\begin{array}{l}\text { B1.1 Low rate } \\
\text { of renewable } \\
\text { energy use }\end{array}$} & 13 & $\begin{array}{l}\text { Install on-site renewable energy generation } \\
\text { systems }\end{array}$ & - & $\begin{array}{l}\text { (1), (2), (3), } \\
\mathbf{4}, \mathbf{5}, \mathbf{6}, \\
\mathbf{7}\end{array}$ \\
\hline & 14 & Use solar water heating system & A1.1 & (3), $\boldsymbol{7}$ \\
\hline & 15 & $\begin{array}{l}\text { Use geothermal systems, cogeneration, or other } \\
\text { alternatives for water heating and space cooling }\end{array}$ & A1.1 & (3) \\
\hline & 16 & $\begin{array}{l}\text { Incorporate skywell for daylighting and air } \\
\text { movement }\end{array}$ & $\mathrm{B} 1.2, \mathrm{~A} 1.1$ & - \\
\hline & 17 & $\begin{array}{l}\text { Provide daylighting, cross and/or stack natural } \\
\text { ventilation for all public, circulation spaces and } \\
\text { large portion of habitable rooms }\end{array}$ & $\mathrm{B} 1.2, \mathrm{~A} 1.1$ & $\begin{array}{l}\text { (3), } \mathbf{4}, \mathbf{5} \\
\mathbf{6}, \mathbf{7}\end{array}$ \\
\hline & 18 & $\begin{array}{l}\text { Arrange apartment unit's openings in opposite } \\
\text { sides and interior doors to facilitate the cross } \\
\text { ventilation }\end{array}$ & $\mathrm{B} 1.2, \mathrm{~A} 1.1$ & - \\
\hline & 19 & $\begin{array}{l}\text { Enhancing the penetration of daylight by light } \\
\text { color interior surfaces, light shelves }\end{array}$ & - & - \\
\hline
\end{tabular}




\begin{tabular}{|c|c|c|c|c|}
\hline $\begin{array}{l}\text { Primary issue } \\
\text { indicator }\end{array}$ & No. & Proposed strategy as solution & $\begin{array}{l}\text { Secondary } \\
\text { issue } \\
\text { indicator }\end{array}$ & $\begin{array}{l}\text { Reference } \\
\text { sources }\end{array}$ \\
\hline & 20 & $\begin{array}{l}\text { Increase floor-to-ceiling heights and decrease } \\
\text { distance of habitable spaces from windows }\end{array}$ & - & - \\
\hline & 21 & $\begin{array}{l}\text { Planning interior partitions and furniture that } \\
\text { avoids blocking daylight }\end{array}$ & - & - \\
\hline \multirow{2}{*}{$\begin{array}{l}\text { B1.2 High } \\
\text { demand of air- } \\
\text { conditioning } \\
\text { system }\end{array}$} & 22 & $\begin{array}{l}\text { Use operable windows in combination with } \\
\text { mechanical ventilation systems }\end{array}$ & $\mathrm{B} 1.1, \mathrm{C} 2.3$ & - \\
\hline & 23 & Use flexible occupant-controlled openings & $\mathrm{B} 1.1, \mathrm{C} 2.3$ & (1), 6 \\
\hline \multirow[t]{3}{*}{$\begin{array}{l}\text { B1.3 Materials } \\
\text { processing }\end{array}$} & 24 & Use certified wood/timber & $\mathrm{B} 2.2, \mathrm{~B} 2.1$ & (1), 5, 6, \\
\hline & 25 & Minimize the use of highly processed materials & $\mathrm{B} 2.2, \mathrm{C} 2.3$ & - \\
\hline & 26 & Use non-baked materials for non-structural walls & $\mathrm{B} 2.2, \mathrm{C} 2.3$ & 8 \\
\hline \multirow{2}{*}{$\begin{array}{l}\text { B2.1 Land } \\
\text { erosion and } \\
\text { river/canal } \\
\text { pollution }\end{array}$} & 27 & $\begin{array}{l}\text { Recycle/compost landscape and/or organic waste } \\
\text { and incorporate compost to promote healthy } \\
\text { topsoil in landscaping }\end{array}$ & $\mathrm{B} 2.2$ & (5 \\
\hline & 28 & $\begin{array}{l}\text { Preserve the site with existing and adapted } \\
\text { vegetation }\end{array}$ & $\begin{array}{l}\mathrm{B} 3.2, \\
\mathrm{C} 2.3, \mathrm{~A} 1.1\end{array}$ & $\begin{array}{l}\text { (1), (2), (3), } \\
\mathbf{4}, \mathbf{5}, \mathbf{6}, \\
\mathbf{7}\end{array}$ \\
\hline \multirow{7}{*}{$\begin{array}{l}\text { B2.2 High } \\
\text { amount of solid } \\
\text { waste }\end{array}$} & 29 & $\begin{array}{l}\text { Use local/regional materials; natural/organic } \\
\text { materials }\end{array}$ & $\mathrm{B} 1.3, \mathrm{~B} 2.1$ & $\begin{array}{l}\text { (1), (2), (3), } \\
\mathbf{5 ,}, \mathbf{6}, \mathbf{7}\end{array}$ \\
\hline & 30 & $\begin{array}{l}\text { Reuse/renovate an old building; reuse building } \\
\text { nonstructural components }\end{array}$ & $\mathrm{B} 1.3, \mathrm{~B} 2.1$ & $\begin{array}{l}\text { (1), (2), (3), } \\
\mathbf{5 ,}, \mathbf{6}, \mathbf{7}\end{array}$ \\
\hline & 31 & Use reusable, recyclable materials & $\mathrm{B} 1.3, \mathrm{~B} 2.1$ & (3), 6 \\
\hline & 32 & $\begin{array}{l}\text { Use the reused, refurbished, and recycled } \\
\text { materials }\end{array}$ & B1.3, B2.1 & $\begin{array}{l}\text { (1), (2), (3), } \\
\mathbf{4}, \mathbf{5}, \mathbf{6}, \\
\mathbf{7}\end{array}$ \\
\hline & 33 & $\begin{array}{l}\text { Use materials with appropriate durability, self- } \\
\text { evident care and maintenance }\end{array}$ & $\mathrm{B} 2.1$ & (3) \\
\hline & 34 & $\begin{array}{l}\text { Provide a centralized and easily accessible space } \\
\text { for collection and storage of recyclables }\end{array}$ & B2.1 & $\begin{array}{l}\text { (1), }, \mathbf{5}, \mathbf{6} \\
\mathbf{7}\end{array}$ \\
\hline & 35 & $\begin{array}{l}\text { Design for flexibility and adaptability to future } \\
\text { changes in building use (e.g., layout, building } \\
\text { structures) }\end{array}$ & $\mathrm{C} 1.2$ & (2), (3) \\
\hline \multirow{2}{*}{$\begin{array}{l}\text { B3.1 Low level } \\
\text { land }\end{array}$} & 36 & Locate the building on elevated position & A1.2 & (2), $6, \boldsymbol{7}$ \\
\hline & 37 & Elevated ground floor & $\mathrm{A} 1.2$ & - \\
\hline \multirow{4}{*}{$\begin{array}{l}\text { B3.2 Weak } \\
\text { water } \\
\text { conservation } \\
\text { infrastructure }\end{array}$} & 38 & $\begin{array}{l}\text { Use water-conserving plumbing fixtures and } \\
\text { appliances }\end{array}$ & B2.1 & $\begin{array}{l}\text { (1), (2), (3), } \\
\mathbf{4}, \mathbf{5}, \mathbf{6} \\
\mathbf{7}\end{array}$ \\
\hline & 39 & $\begin{array}{l}\text { Use site-reclaimed water (non-potable water) for } \\
\text { landscape irrigation, or toilet flushing, or cooling } \\
\text { tower }\end{array}$ & B2.1 & 5, 6, 7 \\
\hline & 40 & $\begin{array}{l}\text { Use ecology-based treatment processes for } \\
\text { sewage treatment }\end{array}$ & B2.1 & $\begin{array}{l}\text { (1), (2), (3), } \\
\mathbf{5 ,}, \mathbf{7}\end{array}$ \\
\hline & 41 & $\begin{array}{l}\text { Grey/black water treatment, recycling and reuse } \\
\text { for non-portable purposes }\end{array}$ & B2.1 & $\begin{array}{l}\text { (1), (2), } \mathbf{6} \\
\mathbf{6}, \boldsymbol{7}\end{array}$ \\
\hline \multirow{2}{*}{$\begin{array}{l}\text { C1.1 Lack of } \\
\text { public open } \\
\text { space }\end{array}$} & 42 & Enhance vegetated open space and biodiversity & $\mathrm{C} 2.3, \mathrm{C} 3.1$ & $\begin{array}{l}\text { (1), (2), (3), } \\
\mathbf{6 , \boldsymbol { 7 }}\end{array}$ \\
\hline & 43 & $\begin{array}{l}\text { In site selection, avoid building on } \\
\text { environmentally, culturally, and socially } \\
\text { sensitive sites. }\end{array}$ & C3.1 & $\begin{array}{l}\text { (1), (2), (3), } \\
\mathbf{5}, \mathbf{6}, \mathbf{7}\end{array}$ \\
\hline \multirow[t]{3}{*}{$\begin{array}{l}\text { C1.2 Lack of } \\
\text { greenery land }\end{array}$} & 44 & $\begin{array}{l}\text { Optimize the layout and reduce the development } \\
\text { footprint to save land and natural resources, and } \\
\text { preserve open space }\end{array}$ & $\mathrm{B} 2.1, \mathrm{C} 2.3$ & (1), (2) \\
\hline & 45 & $\begin{array}{l}\text { Rehabilitate a brownfield or previously occupied } \\
\text { site }\end{array}$ & $\mathrm{B} 2.1, \mathrm{C} 2.3$ & $\begin{array}{l}\text { (1), (2), } \mathbf{6} \\
\mathbf{6}, \boldsymbol{7}\end{array}$ \\
\hline & 46 & $\begin{array}{l}\text { Provide limited parking capacity to meet but not } \\
\text { exceed minimum local zoning requirements }\end{array}$ & $\mathrm{C} 2.2$ & (1), 6 \\
\hline
\end{tabular}




\begin{tabular}{|c|c|c|c|c|}
\hline $\begin{array}{l}\text { Primary issue } \\
\text { indicator }\end{array}$ & No. & Proposed strategy as solution & $\begin{array}{l}\text { Secondary } \\
\text { issue } \\
\text { indicator }\end{array}$ & $\begin{array}{l}\text { Reference } \\
\text { sources }\end{array}$ \\
\hline \multirow[t]{2}{*}{$\begin{array}{l}\text { C2.1 } \\
\text { Overloaded } \\
\text { private vehicles }\end{array}$} & 47 & $\begin{array}{l}\text { Provide an amount of preferred parking spots for } \\
\text { buses, sharing vehicles, and high-performance } \\
\text { hybrid vehicles }\end{array}$ & $\mathrm{C} 2.2, \mathrm{C} 2.4$ & (1), 6 \\
\hline & 48 & $\begin{array}{l}\text { Locate preferred parking, bicycle parking, pick- } \\
\text { up areas, and covered waiting spaces close to } \\
\text { main building entrances }\end{array}$ & $\mathrm{C} 2.4$ & 6 \\
\hline \multirow{2}{*}{$\begin{array}{l}\text { C2.2 } \\
\text { Unattractive } \\
\text { public/bus } \\
\text { transportation }\end{array}$} & 49 & $\begin{array}{l}\text { Locate a site in walking distance to public transit } \\
\text { stops }\end{array}$ & $\mathrm{C} 2.4$ & $\begin{array}{l}\text { (1), } \mathbf{6}, \mathbf{6}, \\
\mathbf{7}\end{array}$ \\
\hline & 50 & $\begin{array}{l}\text { Provide public transport information and } \\
\text { assistance for residents }\end{array}$ & $\mathrm{C} 2.4$ & 8 \\
\hline \multirow{3}{*}{$\begin{array}{l}\text { C2.3 Noise, } \\
\text { polluted air, } \\
\text { accidents }\end{array}$} & 51 & Design buildings for noise pollution reducing & - & $\begin{array}{l}\text { (2), (3), } \mathbf{4}, \\
\mathbf{5}, \mathbf{7}\end{array}$ \\
\hline & 52 & $\begin{array}{l}\text { Take into account security, noise and dust } \\
\text { concerns when providing natural ventilation }\end{array}$ & $\mathrm{A} 1.1 ; \mathrm{B} 1.1$ & - \\
\hline & 53 & Positive soundscapes & - & - \\
\hline \multirow{3}{*}{$\begin{array}{l}\text { C2.4 Traffic } \\
\text { congestion }\end{array}$} & 54 & Provide favorable public or private walkway & $\mathrm{C} 2.2, \mathrm{C} 2.3$ & - \\
\hline & 55 & $\begin{array}{l}\text { Provide favorable bicycle lanes and secure and } \\
\text { easily accessible bicycle storage/parking on the } \\
\text { site }\end{array}$ & $\mathrm{C} 2.3$ & (1), 5, 6 \\
\hline & 56 & $\begin{array}{l}\text { Locate a site in walking distance to many } \\
\text { community services and amenities }\end{array}$ & $\mathrm{C} 3.1$ & $\begin{array}{l}\text { (1), 5, 6, } \\
\mathbf{7}\end{array}$ \\
\hline $\begin{array}{l}\text { C3.1 Lack of } \\
\text { community } \\
\text { connectivity }\end{array}$ & 57 & $\begin{array}{l}\text { Incorporate dedicated community facilities } \\
\text { flexible for varied activities (e.g. recreational } \\
\text { facilities, meeting room, childcare facilities, } \\
\text { gardens) }\end{array}$ & $\mathrm{C} 1.1$ & $\boldsymbol{7}$ \\
\hline $\begin{array}{l}\text { C3.2 Low- } \\
\text { rise/Townhouse } \\
\text { living habits }\end{array}$ & 58 & $\begin{array}{l}\text { Proper layout of apartment unit (living, kitchen } \\
\text { and bedroom space) }\end{array}$ & - & - \\
\hline
\end{tabular}

\section{Discussion}

Presently, the architectural designing activities in HCMC has no much concern over the terms of sustainability. The numbers of 'green' buildings designed recently bring about merely formal appearance rather than the real sustainable performance of the building. In addition, various sustainable strategies applied are general strategies rather than straightly contribute to the real issues of HCMC. The result of this research with 58 strategies stemming from the critical issues of HCMC urban is an up-to-date guidance responsible to the actual context of society. The set of strategies is formed on the thinking of applicability, thus it is practical for the designing contemporary HAB in HCMC toward sustainability.

Since the starting points of this strategies building are the critical issues of $\mathrm{HCMC}$, they certainly bypass some aspects of sustainability such as energy consumption issues and VOC emission issues which are the limitation of the above strategies. This research implementation is not the copy of available strategies and criteria but filtering out what is necessary and facilitating to apply to the actual condition. The research contributes highly practical values to HAB built environment in HCMC.

\section{Conclusions}

This study is conducted on the critical issues of HCMC urban and developing the practical set of strategies as solutions to those problems based on the reference of various sustainable criteria. The set of 58 strategies is ready to apply in the actual design process on HAB in HCMC. 


\section{References}

1. G. Brundtland, "Our common future: The world commission on environment and development," Oxford University Press, 1987.

2. ISO, "ISO/DIS 15392, Sustainability in building construction - general principles," International Organization for Standardization, 2006.

3. Phê duyệt chiến lược phát triển bền vững Việt Nam giai đoạn 2011-2020," P. Minister, ed., 2012.

4. Approval of national housing development strategy to 2020 and vision to 2030 [in Vietnamese]," P. Minister, ed., 2011.

A. D. Tran. "Phát triển nhà ở cao tầng Thành phố Hồ Chí Minh theo hướng xanh - hiện đại - bản sắc," October 15, 2014; http://118.70.241.18/english3/news/?41939/Phat-triennha-o-cao-tang-Thanh-pho-Ho-Chi-Minh-theo-huong-xanh---hien-dai---ban-sac.htm.

5. "Gỡ vướng trong phát triển nhà ở tại TP Hồ Chí Minh," October 15, 2014; http://cand.com.vn/dia-oc/Go-vuong-trong-phat-trien-nha-o-tai-TP-Ho-Chi-Minh$372833 /$.

6. N. H. Giang, "Giải pháp thiết kế nhà ở cao tầng tại TP.Hồ Chí Minh theo hướng đảm bảo điều kiện tiện nghi vi khí hậu \& sử dụng năng lượng có hiệu quả [Design Methods for High-Rise Housing in Ho Chi Minh towards Micro-Climatic Comforts and Energy Efficiency]," Master thesis, University of Architecture Ho Chi Minh City, Ho Chi Minh, 2007.

7. T. H. N. Le, "An Analysis of Passive Design and Unique Spatial Characteristics Inherent in Vietnamese Indigenous Housing and Their Applications to Contemporary High-Rise Housing in Vietnam," Doctoral dissertation, Inha University, Incheon, 2011.

8. N. H. L. Truong, "Developing Design Guidelines Framework for Sustainable High-Rise Apartment Buildings in Ho Chi Minh City,” Doctoral dissertation, Seoul National University, 2016.

9. N. H. Giang, "Hệ thống tiêu chí Kiến trúc bền vững áp dụng cho thiết kế nhà ở cao tầng tại Thành phố Hồ Chí Minh [Criteria system of sustainable architecture for designing high-rise housing in Ho Chi Minh City]," Doctoral dissertation, University of Architecture Ho Chi Minh City, 2016.

10. Vietnam Ministry of Construction, QCVN 02: 2009/BXD Vietnam building code Natural Physical \& Climatic Data for Construction, Hanoi: Vietnam Ministry of Construction, 2009.

11. "Khí hậu, thời tiết," October 15, 2015; http://www.hochiminhcity.gov.vn/thongtinthanhpho/gioithieu/Lists/Posts/Post.aspx?L ist $=9$ efd 7 faa-f6be-4c91-9140-e2bd40710c29\&ID $=5497 \& W e b=9 d 294 a 7 f-c a f 2-456 d-$ $8 \mathrm{ca} 0-36 \mathrm{~b} 393 \mathrm{~b} 8 \mathrm{c} 052$.

12. S. Dasgupta, B. Laplante, C. Meisner et al., "The impact of sea level rise on developing countries: a comparative analysis," World Bank policy research working paper, no. 4136, 2007.

13. Asian Development Bank, Viet Nam : environment and climate change assessment, 2013.

14. "Biến đổi khí hậu và Hiệu ứng đảo nhiệt đô thị ở ТPHCM," June 15, 2015; http://quanlidothi.com/xem/1089/bien-doi-khi-hau-va-hieu-ung-dao-nhiet-do-thi-otphcm.html.

15. H. Long Phi, "Inundation and Stormwater Drainage in Ho Chi Minh City." 
16. K. Nihon Enerugi Keizai, APEC energy demand and supply outlook, Tokyo: Asia Pacific Energy Research Centre, Institute of Energy Economics, Japan, 2013.

17. G. McGranahan, D. Balk, and B. Anderson, "The rising tide: assessing the risks of climate change and human settlements in low elevation coastal zones," Environment and Urbanization, vol. 19, no. 1, pp. 17-37, 2007.

18. Ministry of Natural Resources and Environment, Climate Change, Sea Level Rise Scenarios for Vietnam, Hanoi, 2009.

19. "TCXDVN 362-2005 Quy hoạch cây xanh sử dụng công cộng trong các đô thị - Tiêu chuẩn thiết kế," M. o. Construction, ed., 2006.

20. "Phê duyệt dự án quy hoạch công viên cây xanh Thành phố Hồ Chí Minh," P. s. C. o. HCMC, ed., 2000.

21. Van Nam. "TPHCM: Diện tích công viên giảm gần 50\%," October 15, 2014; http://www.thesaigontimes.vn/Home/dothi/hatang/27565/.

22. "Định hướng chiến lược phát triển bền vững ở Việt Nam (Chương trình Nghị Sự 21 của Việt Nam)," P. Minister, ed., 2004.

23. H. L. Phan, C. Tu, D. N. Nguyen et al., The Traditional Village in Vietnam, Hanoi: The Gioi, 1993. 